\title{
Fertigation for Environmentally Friendly Fertilizers Application: Constraints and Opportunities for Its Application in Developing Countries
}

\author{
Michel Kabirigi ${ }^{*}$, Shrestha Om Prakash ${ }^{2}$, Boejharat Varsha Prescella ${ }^{3}$, Crissy Niamwiza4, \\ Serrano Pitti Quintin'5, Israel Anyisile Mwamjengwa6, Abeykoon Mudiyanselage Jayantha7, \\ Mary Logunu Apula Keji ${ }^{8}$, Chenglin Zhang9
}

\author{
${ }^{1}$ Rwanda Agriculture Board (RAB), Soil and Water Management Program of Research Department, Kigali, Rwanda \\ ${ }^{2}$ Paurakhi Samudayik Krisi Sahakari Santa Ltd., Bahktadur, Nepal \\ ${ }^{3}$ Anton de Kom University, Leysweg, Suriname \\ ${ }^{4}$ Ministry of Lands, Natural Resources and Environmental Protection, Forestry Department, Mongu, Zambia \\ ${ }^{5}$ Ministry of Agriculture, Panama, Agencia Río Sereno, Chiriqui, Panama \\ ${ }^{6}$ Tanzania Bureau of Standards (TBS), Testing and Calibration Department, Dar es salaam, Tanzania \\ ${ }^{7}$ Department of Agriculture, Colombo, Sri Lanka \\ ${ }^{8}$ Ministry of Agriculture, Juba, South Sudan \\ ${ }^{9}$ South China Agricultural University, Guangzhou, China \\ Email: *kabirimi@yahoo.fr
}

\begin{abstract}
How to cite this paper: Kabirigi, M., Prakash, S.O., Prescella, B.V., Niamwiza, C., Quintin, S.P., Mwamjengwa, I.A., Jayantha, A.M., Keji, M.L.A. and Zhang, C.L. (2017) Fertigation for Environmentally Friendly Fertilizers Application: Constraints and Opportunities for Its Application in Developing Countries. Agricultural Sciences, 8, 292301. https://doi.org/10.4236/as.2017.84021
\end{abstract}

Received: February 2, 2017

Accepted: April 27, 2017

Published: April 30, 2017

Copyright ( 92017 by authors and Scientific Research Publishing Inc. This work is licensed under the Creative Commons Attribution International License (CC BY 4.0).

http://creativecommons.org/licenses/by/4.0/ (c) $\underset{\mathrm{EY}}{\text { (i) Open Access }}$

\begin{abstract}
There is an increasing concern about agriculture's role in polluting the environment which makes farmers feel guilty about using fertilizers. Fertigation is proposed as a panacea to this dilemma, which by this practice reaffirms the principles of 4 Rs which are the right source, at the right rate, right time and right place. The aim of this study was to explore constraints and opportunities for its application in developing countries for environmentally friendly fertilizers application. It is a review of literature from government reports, legislature and published material on fertilization and irrigation initiatives of developing countries which include Rwanda, Nepal, Suriname, Zambia, Panama, Tanzania, Sri Lanka and South Sudan in addition to the case presented of China during the "2016 Environmentally Friendly Fertilizer Production, Application and Demonstration from Developing Countries" training course. The study found that in developing countries there is potential to apply fertigation as a way of environmentally friendly fertilizers application as it has been adopted in China. These opportunities include the following: Abundant natural resources like land and water, less polluted environment, conducive agricultural policies, zero duties levied on imported irrigation equipment.
\end{abstract}


However, a number of limitations also are highlighted including: Lack of investment, lack of infrastructure, lack of information, requires expertise on plant nutrition and management of fertigation system, require soil analysis and proper interpretation which is done by experts. This study provides relevant information for fertigation planning and application in respective developing countries.

\section{Keywords}

Fertigation, Environmentally Friendly, Developing Countries

\section{Introduction}

There is an increasing concern about agriculture's role in polluting the environment which makes farmers feel guilty about using fertilizers [1]. Intensification of agriculture by irrigation and enhanced use of fertilizers may generate pollution by increased levels of nutrients in underground and surface waters [2]. Inorganic fertilizers have been reported as potential sources of pollution which upset the balance of the ecosystem. With fertilization nitrogen-oxide, a greenhouse gas, can escape into the atmosphere, nitrates can leach into the groundwater, surface runoff water from the fields can transports phosphorus, ammonia and nitrate to water reservoirs and rivers [1]. In developing countries, agriculture has been a judicious driver of well-being for centuries, ensuring food security and catalyzing productivity required for economic success [3]. Consequently, reducing fertilizers input can lead to reduced plant growth while aggravating problems such as soil erosion though in developing countries there is a need to improve agricultural productivity and water resource use efficiency for meeting food demand and environmental sustainability. From this respect fertigation is proposed as a panacea to this dilemma whereby this practice reaffirms the principles of 4 Rs which are right source, at the right rate, right time and right place [4].

Nutrients and water are considered to be the major components of plant growth. Habitually nutrients are provided to plants by fertilizer after some processing and conversion into available form and water facilitates the distribution of fertilizer as well as fulfills the water requirement of plants [5]. Source of fertilizer and water could be both natural and artificial by human effort. However, many factors like timing, quantity, quality and distribution determine whether the fertilizer and water provided to the plants and crops is appropriate or not [6]. Sometimes, the results are good and sometimes the results are not as expected or bad. If the watering is insufficient, fertilizers cannot reach the roots and excess watering makes the fertilizer leach down much lower than the root levels and in both cases the plants cannot get sufficient nutrients required for growth. Both less or excess watering cases are unfavorable to the plants as well as environment as volatilization or esterification take place causing nutritional deficiency of plants and pollution of environment.

System of fertigation has been developed to tackle this imbalanced situation 
and take control of supply of nutrients and water to plants with proven results [2]. Fertigation basically means injection of fertilizers, soil amendments, and other water-soluble products into an irrigation system. In other words, appropriate amount of fertilizer and water are supplied to the plants just according to the requirements [7]. This fertigation system has multifold benefits like, it is very efficient in supplying nutrients to the plants while it is economic with lower cost on labor and fertilizer, and it is environmentally friendly as well.

Developing countries have potentials for agricultural production with of course some limitations. However, these are poorly known or miss interpreted. In developed countries the damage caused to the environment with fertilizers application is less compared to developed countries which insure the potential to prevent over-fertilization and pollution. It is hypothesized that the introduction of new technologies such as fertigation will bring even better results and a reduction in the consumption of fertilizers for grain production. This paper comes to highlight constraints and opportunities for application of fertigation for environmentally friendly fertilizers application in developing countries. This provides a baseline for further studies as well as investment plans of fertigation practice.

\section{Methodology}

This paper arises from combined effort of some participants in the training course on "Environmentally Friendly Fertilizer Production, Application and Demonstration from Developing Countries" which was organized by South China Agricultural University and sponsored by the Ministry of Commerce of People's Republic of China in 2016. It is a review of literature from government reports, legislature and published material on fertilization and irrigation initiatives of developing countries which include Rwanda, Nepal, Suriname, Zambia, Panama, Tanzania, Sri Lanka and South Sudan in addition to the case presented of China during the training course. The main idea is to discuss constraints and opportunities of fertigation towards environmentally friendly fertilizers application. Data presented in this paper consist of background of these countries regarding important parameters that contribute to the success of a fertigation plan. Other peer reviewed publication were consulted to discuss countries conditions and how fertigation would leads to both fertilizers and water use efficiency as well as reducing pollution to the environment the practice known as "Environmentally Friendly Fertilizers application". The information was gathered in a systematic way whereby the first priority was given to a scientifically peer reviewed source of information (Peer reviewed papers). The second priority was given to the year of publication and thus recently published papers were highly considered. The third priority was given to the paper's response to the discussed issues.

\section{Main Findings}

\subsection{Fertigation: An Overview}

Fertigation refers to a method of fertilizer application in which fertilizer is in- 
corporated within an irrigation system [8]. Its development was driven by increasing labor costs, demands to prevent pollution and to minimize soil erosion, increasing reliance on saline water sources, and unfavorable soil quality and wind conditions. The fertigation technique has rapidly spread all over the world in the last 40 years [9] as a tool to supply the plant with its daily demand of water and nutrients as required by its specific growth stage throughout its development to achieve maximum efficiency of the fertilizer applied [10]. The main reported benefits of fertigation are: 1) Nutrients and water are supplied near the active root zone which results in greater absorption by the crops, 2) As water and fertilizer are supplied evenly to all the crops there is possibility for getting higher yield, 3) Fertilizer use efficiency is high which helps to save nutrients, 4) By this way, along with less amount of water and saving of fertilizer, time, labour and energy use is also reduced substantially [11]. Using this "spoon feeding" approach to fertilization, the units of fertilizer application in fertigation are calculated on the basis of individual plant demand expressed in units of milligram of nutrient $(\mathrm{N}, \mathrm{P}$ or $\mathrm{K})$ per day over the entire growing period. By adopting this approach, readily soluble nutrients can be supplied directly to the root volume thereby maximizing nutrient efficiency and minimizing over fertilization and leakage to underground water with possible damage to the environment. Fertigation is practiced extensively in commercial agriculture and horticulture [2] [8] [9] [10] and in high-value crops such as vegetables, turf, fruit trees, and ornamentals. Fertigation is also increasingly being used for landscaping as dispenser units become more reliable and easier to use. Fertigation is used to add additional nutrients or to correct nutrient deficiencies detected in plant tissue analysis.

\subsection{Fertigation in China}

Fertigation receives a great deal of interest in China because of the potential to increase agricultural productivity, while at the same time, save water and nutrients. The technology has been initiated in China by the Chinese National Agro Dtechnical Extension and Service Centre (NATESC) and the International Potash Institute (IPI) in the late 1990s, responding to this need. From then a series of activities at farm and extension level to demonstrate the benefits of fertigation through publications, field experiments, training courses and famers' days were started. These efforts yielded a wide acceptance of fertigation by scientists, extension officers and policy makers in China [4]. It was highlighted by Thamara, Kumar [12] that maximum crop yield parameters can be obtained by application of water soluble fertilizers through fertigation. In recent years, fertigation has become more and more popular in the banana production areas in China, especially for the large-scale growers. Currently fertigation technology is widespread in China as an environmentally friendly fertilizers application method, particularly in the North and North-west regions, where water shortage is very serious [13]. 


\subsection{Study Countries General Background}

Summary of respective study countries background information is presented in Table 1. Agriculture lands in Tropical regions present a similar scenario in regard to arable $\%$ in relation to the total land area. The arable land in Tanzania, Nepal, Sri Lank, Rwanda and Zambia ranged from a minimum of $40 \%$ to above $60 \%$ against the total land area. Furthermore a similar scenario occurs among these countries towards contribution of labor to the agriculture sector (above $60 \%)$ than in any other sectors in their respective countries. The data is further supported by the considerable contribution of the agriculture sector towards the GDP to the majority of respective study countries. However, suffice to note that the scenario is somehow different from countries such as Panama, Suriname and South Sudan despite having similar tropical climates. These countries arable land \% against the total land area is very minimal. All the three countries fall below $10 \%$ arable land against the total land area. Further they are coupled with low labor force in the agricultural sector and low contribution to the GDP's countries respectively. This can be attributed to a number of factors. Panama's canal provides the main source of their economic drive thus a driving force to maritime services. They in turn bring to the fore banking and commerce all providing $67 \%$ while agriculture provides $25 \%$ of employment respectively. Suriname's economy drive relays greatly on gold and oil exports. Hence its low agriculture significance contribution to its country's GDP. Equally South Sudan's dependence on rich petroleum and mineral deposits contribute to low agricultural activities despite potential in rich fertile arable land.

Table 1. Summary of respective study countries background.

\begin{tabular}{ccccccccc}
\hline Parameter & Tanzania & Rwanda & Panama & Sri Lanka & S. Sudan Suriname & Nepal & Zambia \\
\hline $\begin{array}{c}\text { Country area } \\
(\text { Sq } \mathrm{km})\end{array}$ & 945,087 & 26,338 & 75,420 & 65,610 & 644,329 & 163,265 & 147,181 & 752,614 \\
$\begin{array}{c}\text { Total } \\
\text { population }\end{array}$ & $53,470,00011,149,0083,864,000$ & $19,905,165$ & $12,339,812$ & 542,975 & $28,440,34013,600,000$ \\
$\begin{array}{c}\text { Agriculture } \\
\text { arable land \% }\end{array}$ & 42 & 75 & 10 & 65 & 4.3 & 9.15 & 40 & 58 \\
$\begin{array}{c}\text { Irrigation } \\
\text { land (ha) }\end{array}$ & 356,514 & 40,707 & 40,380 & & & 33,000 & & 156,000 \\
$\begin{array}{c}\text { \% Pop. in } \\
\text { agriculture }\end{array}$ & 67 & 89 & 25 & 32 & & 8 & 66 & 60 \\
$\begin{array}{c}\text { Population } \\
\text { density }\end{array}$ & $62 / \mathrm{Km}^{2}$ & $482 / \mathrm{Km}^{2}$ & $54 / \mathrm{Km}^{2}$ & $320 / \mathrm{Km}^{2}$ & $21 / \mathrm{Km}^{2}$ & $4 / \mathrm{Km}^{2}$ & $201 / \mathrm{km}^{2}$ & $21 / \mathrm{Km}^{2}$ \\
$\begin{array}{c}\text { Population } \\
\text { growth rate }\end{array}$ & $3.2 \%$ & $2.8 \%$ & $1.3 \%$ & $0.9 \%$ & $3.2 \%$ & $1.1 \%$ & $1.8 \%$ & $2.1 \%$ \\
$\begin{array}{c}\text { GDP Per } \\
\text { Capita (USD) }\end{array}$ & 1700 & 1500 & 16,500 & 6500 & 1400 & 12,900 & 1500 & 1800 \\
$\begin{array}{c}\text { Agriculture \% } \\
\text { contribution } \\
\text { to GDP }\end{array}$ & $48.0 \%$ & $33.6 \%$ & $7.0 \%$ & $19.9 \%$ & $4.0 \%$ & $0.1 \%$ & $32.5 \%$ & $21.0 \%$ \\
\hline
\end{tabular}




\subsection{Soil Considerations in Fertigation}

Soil is a key element in fertigation as it can lead to its failure or success if it is not properly taken care of. Soil elements which need to be assessed before application of fertigation include: Soil moisture content as well as holding capacity, Oxygen regime, Soil texture and infiltration rate, Salt content in soil, Available nutrients in the soil as well as alkalinity and acidity. Soil texture will dictate the emitters flow rates and distance between them, when fertigation is done using drip system of irrigation.

Table 2 presents soil characteristics for study respective countries. Oxisol is the most dominant soil type while most of countries soils are slightly acidic. The elevation is highly variable depending on the country however most countries are mountainous as far as topography is concerned.

It has been discussed that the actual water distribution from a point source in the field is very much affected by a number of soil related factors including the type and clay content of the soil, mechanical soil surface preparations, the soil's chemical composition, as well as lime content and salinity or sodicity development due to irrigation [14]. Soil acidity is the most critical soil condition since plants and soil micro-organisms have preferences for soil within certain $\mathrm{pH}$ ranges, usually neutral to moderately acid or alkaline [15]. According to FAO Acid soils are those that have a $\mathrm{pH}$ value of less than 5.5 for most of the year. They are associated with a number of toxicities (Aluminum) as well as deficiencies (Molybdenum) and other plant restricting conditions. Merry [16] stated that $\mathrm{pH}$ measurement, are fundamental to understanding the nature and behavior of many soils which is also applicable when planning a fertigation system.

\subsection{Types of Fertilizers in Fertigation}

Table 3 shows the list of different types of fertilizers used in study developing countries, Different types of fertilizers (both solid and liquid) are applied in agriculture. Fertilizers used in most of the countries are Urea, NPK, and DAP, while TSP and MOP is also used in Tanzania and Sri Lanka. The South Sudan is not using any chemical fertilizer in agriculture production. None of these countries produce chemical fertilizer except Tanzania producing organic hyper phosphate (Minjingu Mine and Fertilizer LTD) and Zambia producing Urea (Zambian Fertilizers LTD). All chemical fertilizers used by these countries are

Table 2. Summary of dominant soils in respective study countries.

\begin{tabular}{|c|c|c|c|c|c|c|c|c|}
\hline Parameter & Rwanda & Panama & Zambia & Tanzania & Suriname & Nepal & Sri Lanka & S. Sudan \\
\hline Dominant types & $\begin{array}{l}\text { Inceptisols, } \\
\text { Oxisol, Andosol }\end{array}$ & $\begin{array}{l}\text { Andosol, } \\
\text { Histosol, } \\
\text { Vertisol }\end{array}$ & $\begin{array}{l}\text { Sandy } \\
\text { Alfisols }\end{array}$ & $\begin{array}{l}\text { Cambisol and } \\
\text { Sandy Oxissol }\end{array}$ & $\begin{array}{c}\text { Oxisol } \\
\text { Inceptisols } \\
\text { Cambisols }\end{array}$ & $\begin{array}{c}\text { Alluvial, } \\
\text { Lacustrine, Rocky }\end{array}$ & RBP, RYL & $\begin{array}{c}\text { Ferralsols } \\
\text { (Oxysol) }\end{array}$ \\
\hline Topography & $900-4.507 \mathrm{~m}$ & $0-2475 \mathrm{~m}$ & $915-1500$ & $900-1800$ & $0-1280 \mathrm{~m}$ & $\begin{array}{c}60-8848 \mathrm{~m} \\
\text { Mt Everest }\end{array}$ & $0-2400 \mathrm{~m}$ & \\
\hline Acidity & $\begin{array}{l}\text { 20\% Below 5, } \\
\text { 85\%between 5- } 6\end{array}$ & $\begin{array}{c}64 \% \text { Above } 5 \\
36 \% \text { below } 5\end{array}$ & $\begin{array}{l}\text { More than } \\
30 \% \text { acidic }\end{array}$ & pH $4-6$ & $\begin{array}{l}\text { pH mostly } \\
\text { below } 6\end{array}$ & pH $5.5-6.5$ & pH $5-7$ & pH 5 - 7 \\
\hline
\end{tabular}


Table 3. Summary of fertilizers use in respective study countries.

\begin{tabular}{|c|c|c|c|c|c|c|c|c|}
\hline Parameter & Rwanda & Panama & Zambia & Tanzania & Suriname & Nepal & Sri Lanka & S. Sudan \\
\hline Types & $\begin{array}{c}\text { NPK, } \\
\text { Urea, DAP }\end{array}$ & $\begin{array}{l}\text { NPK, Urea, } \\
\text { DAP, MAP }\end{array}$ & $\begin{array}{l}\text { NPK, Urea, } \\
\text { DAP }\end{array}$ & $\begin{array}{l}\text { NPK, CAN, } \\
\text { DAP, Urea, TSP, } \\
\text { MOP }\end{array}$ & $\begin{array}{l}\text { NPK, } \\
\text { Urea, } \\
\text { DAP }\end{array}$ & $\begin{array}{l}\text { Urea, } \\
\text { DAP, } \\
\text { NPK }\end{array}$ & $\begin{array}{l}\text { Urea, MOP, } \\
\text { TSP, Calcium } \\
\text { Nitrate, } \\
\text { Magnesium } \\
\text { sulphate }\end{array}$ & NONE \\
\hline Ration & $30 \mathrm{~kg} / \mathrm{ha}$ & $50 \mathrm{~kg} / \mathrm{ha}$ & $8 \mathrm{~kg} / \mathrm{ha}$ & - & & $24 \mathrm{~kg} / \mathrm{ha}$ & & \\
\hline Home made & None & No Data & $\begin{array}{l}\text { Compound } \\
\text { D Urea }\end{array}$ & $\begin{array}{c}\text { Minjingu } \\
\text { Super-phosphate }\end{array}$ & NONE & NONE & NONE & NONE \\
\hline Imported & All & All & $\begin{array}{l}\text { NPK, Urea, } \\
\text { DAP }\end{array}$ & $\begin{array}{l}\text { NPK, CAN, DAP } \\
\text { UREA }\end{array}$ & ALL & ALL & ALL & NONE \\
\hline
\end{tabular}

imported.

All mineral nutrients can be supplied to plant roots using fertigation. Generally, though, it is usually only the major nutrients-nitrogen $(\mathrm{N})$, phosphorus $(\mathrm{P})$ and potassium $(\mathrm{K})$, that are supplied using this method, calcium $(\mathrm{Ca})$, magnesium $(\mathrm{Mg})$ and Sulphur $(\mathrm{S})$ are sometimes also supplied. The other essential micronutrients such as boron $(\mathrm{B})$, iron $(\mathrm{Fe})$, manganese $(\mathrm{Mn})$, zinc $(\mathrm{Zn})$, copper $(\mathrm{Cu})$ and molybdenum $(\mathrm{Mo})$ is possible, but these nutrients are generally applied as foliar sprays because only small amounts are needed (Michael T. et al. 2011)

The chemical compositions of soluble single-nutrient and compound fertilizers produced by the fertilizer industry are usually almost the same worldwide [10]. The use of fertilizers is not uniform in particular in developing countries only a minor group of farmers use synthetic fertilizers, while the majority produces at a subsistence level based on crop rotation, recycling of crop residues, organic wastes and animal excreta [17]. In South Sudan, comprehensive list of ongoing donor-funded capacity building and technical support is not available for the Ministry of Agriculture and the state government ministries responsible for the agriculture sector and the country is in civil war that is why agricultural sector is constrained by weak entrepreneurship base and the absence of commercial orientation with little fertilizer application has progressively lowered yields and depleted soils.

\subsection{Water Sources and Pumping System}

When you think of an irrigation system the first equation to solve is where your water source is and what is the proper pumping system to use as energy required for operating pumping stations in irrigation may be significant [18]. Table 4 gives the summary of water availability information in respective study countries. The main water sources in study developping countries are rivers and lakes, in addition to rainfall. In some developing countries irrigation system is available to use gravidity system, which is an advantage because it reduces the operational cost. In other places you can use the ground water however special equipments are needed for deep borehole drilling. For countries like Panama 
Table 4. Summary of water availability in respective study countries.

\begin{tabular}{|c|c|c|c|c|c|c|c|c|c|}
\hline Sources of Water & Parameter & Rwanda & Panama & Zambia & Tanzania & Suriname & Nepal & Sri Lanka & S. Sudan \\
\hline Rainfall & $\begin{array}{c}\text { Average } \\
\text { annual total } \\
(\mathrm{mm})\end{array}$ & $800-2400$ & $\begin{array}{c}\text { Coasts } \\
2600-5500, \\
\text { Mountain } \\
\text { ranges } \\
4000-7000, \\
\text { Azuero } \\
\text { Peninsula } \\
1000-1500\end{array}$ & $900-1500$ & $1000-3000$ & $1750-3000$ & $500-2500$ & $1750-2500$ & \\
\hline $\begin{array}{c}\text { Rainfall } \\
\text { Distribution }\end{array}$ & & $\begin{array}{c}\text { Uneven and } \\
\text { erratic }\end{array}$ & $\begin{array}{l}\text { Uneven and } \\
\text { erratic }\end{array}$ & $\begin{array}{c}\text { Uneven and } \\
\text { erratic }\end{array}$ & $\begin{array}{l}\text { uneven and } \\
\text { erratic }\end{array}$ & $\begin{array}{c}\text { uneven } \\
\text { distribution }\end{array}$ & Uneven & Uneven & Uneven \\
\hline \multirow[t]{2}{*}{ Other sources } & & Lakes, Rivers & $\begin{array}{l}\text { Lakes, Rivers, } \\
\text { Ground water }\end{array}$ & $\begin{array}{l}\text { Lakes, Rivers, } \\
\text { Ground water }\end{array}$ & $\begin{array}{l}\text { Ocean, lake, } \\
\text { river and } \\
\text { under-ground }\end{array}$ & $\begin{array}{c}\text { rivers, lakes, } \\
\text { fresh water } \\
\text { swamps }\end{array}$ & $\begin{array}{l}\text { Rivers, lakes, } \\
\text { under-ground }\end{array}$ & $\begin{array}{l}\text { Rivers, lakes, } \\
\text { Reservers, } \\
\text { Agro well }\end{array}$ & Lake, Rivers \\
\hline & Quantity & & $\begin{array}{c}150,369 \\
\mathrm{~mm}^{3} / \text { year }\end{array}$ & & & & $\begin{array}{l}210,200 \\
\mathrm{~mm}^{3} / \mathrm{yr}\end{array}$ & & \\
\hline
\end{tabular}

and Sri Lanka, the most common pumping systems used are diesel or gas centrifugal pumps due to the lack electrical energy in the production fields. This raises the need for adoption of solar panel system as a solution to this problem. Currently this technology for pumping system in study developping countries has not been development.

\section{Opportunities and Constraints for Application of Fertigation in Study Developing Countries}

Data above presented show that in developing countries there is potential to apply fertigation as a way of environmentally friendly fertilizers application. These opportunities include the following: Abundant natural resources like land and water, less polluted environment, conducive agricultural policies, zero duties levied on imported irrigation equipment, Country's vigorous commercial and corporate farming sector accounting for two-third of irrigated area development. However a number of limitations also are highlighted including: Lack of investment, lack of infrastructure, lack of information, requires expertise on plant nutrition and management of fertigation system, require soil analysis and proper interpretation which is done by experts and different requirements for different crops.

\section{Conclusions and Policy Implications}

Since both fertilization and irrigation are the most important factors in the agriculture and fertigation is one of the best and economic solutions, it should be made widespread in developing countries like ours. With one time investment on necessary simple equipment and accessories, farmers can save on labor, time, money and moreover, they can realize higher yield in harvest as the fertigation system provides nutrients in a balanced way. Considerable efforts have been 
concentrated on applying NPK fertilizers but current research should be centered to a "balanced crop nutrition" approach meaning that fertilizers supply considering other nutrients that are lacking in the soil.

Farmers should be made familiar to this system through trainings, radio and television programs, demonstration field visits. Special recognition to the products of fertigation farming system should also be given to encourage the producers by promoting these products to the consumers in terms of environmental benefits. Government of developing countries should provide technical support, easy loans and subsidy to farmers to setup fertigation systems.

Fertigation also seeks constantly modernized with respect to environmentally friendly fertilizers application system. It is important to monitor and study the crop and adepts its production techniques according to new research findings. Last but not least welcomes the collaboration with national and international research institutes in order to further develop the knowledge of fertigation for environmental friendly fertilizers application and to make the acquire knowledge accessible to others. Results of this review apply also to developing countries having similar conditions as selected study countries.

\section{Acknowledgements}

This review paper is a result of a training course on "Environmentally Friendly Fertilizer Production, Application and Demonstration from Developing Countries" which was organized by South China Agricultural University and sponsored by the Ministry of Commerce of People's Republic of China in 2016. Authors acknowledge the assistance of Ms Li Huiling and Mr Kevin during our stay in South China Agricultural University.

\section{References}

[1] Hu, X.K., et al. (2013) Greenhouse Gas Emissions from a Wheat-Maize Double Cropping System with Different Nitrogen Fertilization Regimes. Environmental Pollution, 176, 198-207. https://doi.org/10.1016/j.envpol.2013.01.040

[2] Hagin, J. and Lowengart, A. (1995) Fertigation for Minimizing Environmental Pollution by Fertilizers. Fertilizer research, 43, 5-7. https://doi.org/10.1007/BF00747675

[3] Kanza, P. and Vitale, J. (2015) Agriculture in Developing Countries and the Role of Government: Economic Perspectives. 2015 AAEA \& WAEA Joint Annual Meeting, 26-28 July 2015, San Francisco, Number 205362.

[4] Imas, P. and Price, M. (2008) Fertigation: Optimizing the Utilization of Water and Nutrients. Fertigation Proceedings: Selected Papers of the IPI-NATESC-CAUCAAS International Symposium on Fertigation, Beijing, 20-24 September 2005.

[5] Jones Jr, J.B. (2012) Plant Nutrition and Soil Fertility Manual. CRC Press, Boca Raton. https://doi.org/10.1201/b11577

[6] Neilsen, D. and Neilsen, G. (2005) Fertigation of Deciduous Fruit Trees: Apple and Sweet Cherry. Fertigation Proceedings: Selected Papers Presented at the Joint, 20, 76.

[7] Li, D.G., Xu, X.C. and Zhang, Y.L. (2002) Fertigation and Fertilizer. Journal of Zhengzhou University of Technology, 1, 21.

[8] Alva, A.K. (2005) Role of Fertigation in Horticultural Crops: Citrus. Fertigation 
Proceedings: Selected Papers Presented at the Joint, 20, 61.

[9] Kafkafi, U. (2005) Global Aspects of Fertigation Usage. Fertigation Proceedings: International Symposium on Fertigation, Beijing, 20-24 September 2005.

[10] Kafkafi, U. and Tarchitzky, J. (2011) Fertigation: A Tool for Efficient Fertilizer and Water Management. International Fertilizer Industry Association, Paris.

[11] Chen, W. et al. (2010) Evaluating Salinity Distribution in Soil Irrigated with Saline Water in Arid Regions of Northwest China. Agricultural Water Management, 97, 2001-2008. https://doi.org/10.1016/j.agwat.2010.03.008

[12] Thamara, M. et al. (2010) Effect of Fertigation on Flower Yield and Quality of China Aster under Open Condition. Mysore Journal of Agricultural Sciences, 44, 39-43.

[13] Xiu, K.W. and Ying, Y.X. (2016) Evaluation of the Effect of Irrigation and Fertilization by Drip Fertigation on Tomato Yield and Water Use Efficiency in Greenhouse. International Journal of Agronomy, 1, 1-10.

[14] Joris, H.A.W., et al. (2013) Effects of Soil Acidity and Water Stress on Corn and Soybean Performance under a No-Till System. Plant and soil, 365, 409-424. https://doi.org/10.1007/s11104-012-1413-2

[15] Bernert, M.R., et al. (2015) Characteristics of PH and Electrical Conductivity on the Fertigation Management. Applied Research \& Agrotechnology, 8, 80-87.

[16] Merry, R. (2009) Acidity and Alkalinity of Soils. Environmental and Ecological Chemistry, 2.

[17] Sidhu, S.S. (1992) Development of a Competitive Free Market Structure for Fertilizers in Bangladesh: IFDC Experience in Policy Reform. IFDC, Muscle Shoals, Alabama.

[18] Moradi-Jalal, M.M., Marino, A. and Afshar, A. (2003) Optimal Design and Operation of Irrigation Pumping Stations. Journal of Irrigation and Drainage Engineering, 129, 149-154. https://doi.org/10.1061/(ASCE)0733-9437(2003)129:3(149)

\section{Submit or recommend next manuscript to SCIRP and we will provide best service for you:}

Accepting pre-submission inquiries through Email, Facebook, LinkedIn, Twitter, etc. A wide selection of journals (inclusive of 9 subjects, more than 200 journals) Providing 24-hour high-quality service User-friendly online submission system Fair and swift peer-review system Efficient typesetting and proofreading procedure Display of the result of downloads and visits, as well as the number of cited articles Maximum dissemination of your research work

Submit your manuscript at: http://papersubmission.scirp.org/

Or contact as@scirp.org 